\title{
Gender and Middle-East: An Intersectionality Perspective
}

\author{
Rajdeep Singh \\ Regional Studies, University of Tehran, Tehran, Iran. E-mail: rajdeepsm@gmail.com \\ Received: April 29, 2019 \\ Accepted: May 15, 2019 Online Published: May 21, 2019 \\ doi:10.5430/elr.v8n2p10 \\ URL: https://doi.org/10.5430/elr.v8n2p10
}

\begin{abstract}
Intersectionality, the relations among different social variables and their interplay, is an inevitable and most employed way of analyzing the gender related issues. We also consider the intersectionality as a great window to new horizons for gender equality aspirations and research. By modifying the more traditional type of intersectional research methodology, we could build up a solid framework for future studies on gender issues particular to the Middle-East. Our goal is to offer a modern model for intersectional studies specific to middle-east, brining onboard different perspectives, usually neglected in mainstream intersectional studies on gender. This model provides a firm ground for psychological questions touching individual as well interpersonal and social dimensions. For this, we concentrate on Iran where the feminist movement is growing fast and there are reasons to believe that it has religious and social texture similar to the rest of the region. We used intersectional methodology as we consider this the most suitable for gender studies. This paper presents a novel model which offers a great unique opportunity to understand the complexity of factors involving the gender issues in a region which is growing fast but still clings to traditions. We further illustrate how the language plays a role in implementing governmental policy which brings about changes in identity and gender inequality.
\end{abstract}

Keywords: Middle-Eastern feminism, Feminist psychology, Social identity, Intersectionality theory, Feminist theory, linguistics

\section{Resumen}

La interseccionalidad, las relaciones entre las diferentes variables sociales y su interacción, es una forma inevitable y muy empleada de analizar las cuestiones relacionadas con el género. Además también consideramos la interseccionalidad como una gran ventana a nuevos horizontes para las aspiraciones de igualdad de género y la investigación en este campo. Al modificar el tipo más tradicional de metodología de investigación interseccional, podríamos construir un marco sólido para futuros estudios sobre temas de género en particular en el Medio Oriente. Nuestro objetivo es ofrecer un modelo moderno para los estudios intersectoriales específicos de Oriente Medio, que incorporen diferentes perspectivas, generalmente descuidadas en los estudios intersectoriales generales sobre género. Este modelo proporciona una base firme para las cuestiones psicológicas que afectan tanto las dimensiones individuales como las interpersonales y sociales. Para esto, nos concentramos en Irán, donde el movimiento feminista está creciendo rápidamente y hay razones para creer que tiene una textura religiosa y social similar al resto de la región. Utilizamos una metodología interseccional, ya que consideramos que esta es la más adecuada para los estudios de género. Este artículo presenta un modelo novedoso que ofrece una gran oportunidad única para comprender la complejidad de los factores que involucran los problemas de género en una región que está creciendo rápidamente pero que aún se aferra a las tradiciones. También ilustramos cómo el lenguaje desempeña un papel en la implementación de la política gubernamental que produce cambios en la identidad y la desigualdad de género.

Palabras clave: feminismo de Oriente Medio; psicología feminista; Identidad social; Teoría de la interseccionalidad; Teoría feminista; lingüística

\section{Introduction}

Intersectional approaches have become widely accepted as essential to contemporary feminism and have been employed especially in European and American context. However, in this paper we examine the feminist movements in the Iranian context under the intersectional theoretical framework. The liveliness of Iranian women rights movements and the overall youth demands for more freedom and equality form the background to analyze the situation for women activism in Iran. We also look at the subtle way linguistics play a role in the veil and gender issues in Iran 
In this paper, we employ the aspect of faith and ethnicity in Iranian case and consider the inclusion of ethnicity as an important category because of its role in the political scene. The discrimination that Iranian women face is a complicated, multi-faceted one, requiring much more philosophical and social dimensions. Singh (2018) builds analyze the identity through the linguistic perspective, connecting language to the social norms. In another works he builds an important model based on the cognitive linguistics for analysis the work of Iranian poet Rajdeep Singh which again shows how even the poetical language can bring about changes in the identity of the readers. (Singh, 2019). Our model also wants to capture different connections that exist between gender inequality and its underlying reasons, affecting how women in the region choose to wear and how that brings out their internal messages, clad in a veil. There are specific critiques with strong voices in a widely expressed concern that feminist scholarship should go more explicit in their acknowledgement regarding the overlapping social positions, norms, traditions and identity. To the extant that one solution was to develop a model of layered oppressions and to put different oppressions based on hierarchical importance. The idea was to show the effects of marginalized identities and that the more marginalized statuses mean the greater the oppression (Purdie-Vaughns and Eibach 2008).

As Shields (2008) points out "connections between feminist psychology and feminist research in other fields have moved far beyond where they were in 1975 when Sex Roles was inaugurated. The influence of feminist research in psychology is quite notable in some areas, such as in the study of violence against women and gender in the workplace, to name just two." Furthermore, we can see that over the past two decades a generative and vital feminist psychology has become openly interdisciplinary in perspective, theory, and methodology (Morawski 1994; Stewart and Dottolo 2006).

Decades have passed since the first sparkles of innovative approach to genders. The present study works on the issue of gender roles in the Middle-East and the opportunities that arise in the horizon for bigger changes in the region. To this end, the intention of this paper is to open a big road in the intersectionality research and to include regional variables that are less present in other regions. In fact, Middle-East is a unique region which complex norms and patriarchal social practices that we cannot simply employ the common intersectional framework to study the region's human rights shortcomings nor to capture the new opportunities there. Building on the works done on the intersection of identity, we will show how including religion variable plays big in the region as the nexus of identity, power and gender.

\section{Iran and Gender Issues}

We consider Iran for developing our model as it presents a social texture similar to other countries in the region and its feminist movement to a great extant has already established itself there. Understanding that social location is important and it helps empirical researchers to conduct researches with considering all the variables influencing their social model. The variables, in our intersectional model, are chosen based on the parliamentary representation of women and their way of considering Hijab in their conscious or unconscious way of dressing. In fact, we believe that this representative of Hijab in the parliament results considerably from how the gender issue is played in the country. Without finding the right variables for social research, there is no way to get a real picture of what is going on in the struggle of feminist streams in the region. The reason we find the variable Hijab as an important one will be further demonstrated in this study.

In March 1979, days after Ayatollah Khomeini rose to power, the American feminist icon Kate Millett traveled to Tehran and she later accompanied her fellow women demonstrators protesting against the Iranian leader's proposal to reinstate a mandatory dress code for women, which is called Hijab since then. In then famous protest, veiled women alongside unveiled women were throwing their fists into the air and chanting equality and liberty for all the women in Iran. Interestingly when the veiled women were asked why they were also protesting, they talked about the respect of personal choice to wear and the objection to eradication of choice. Millet also later asked about the feelings she had for the decision of mandatory dress code and she answered that it was a male chauvinist show. Subsequently she was arrested and expelled in a way she recalled as the most terrifying experience for her (Foreign policy Journal, 2019, March).

The hijab issue is a challenge to the Iranian government as the recent parliamentary report shows that women are increasingly less favorable to the government controlled and imposed dressing code. In the report, only 35 percent of the surveyed women are conscious to the so called "benefits" of wearing the Hijab, while 85 percent of women are opposed to the regulation of government or any enforced imposition of Hijab on women. Another interesting turn is that women are increasingly in favor of the normative veil and hijab wearing, or whatever they deem necessary to wear. In fact, only 45 percent of women consider wearing veil as a religious obligation, while 55 percent wear veil as it is required by the social norms (Iran newspaper, 2018, October). This shows that there is a clear movement within 
society which demands more freedom for women. A look at the Iranian parliament "Majlis" on the women's participation in the politics is fruitful as a good indicator of enthusiasm of Iranian women to be active in the political scene. The second round of the tenth parliamentary elections was held in 55 constituencies in 21 provinces of the country. In the course of the election, the record of the entire history of different parliamentary periods was broken in terms of the number of women attending. In the second round of the tenth parliamentary elections, 136 candidates competed for the appointment of 68 remaining seats in parliament. The election was held in more than 15,000 branches, according to which four other female delegates came to the Islamic Consultative Assembly, or Parliament, in the tenth time, which in the whole accounts to 17 female delegates breaking the previous record of the highest female representation in the Iranian parliament held in the fifth parliament, 1997 parliament ( Tabnak newspaper, April, 2016). However, complete and proper veiled women, "chadori", in Iranian politics are treated differently to women who do not wear Chador, or the complete Hijab. Out of the 17 women in the parliament, only three women dress without Chador or complete Hijab. This shows that in our intersectionality study of the feminism in Iran, we should consider that only a minority of women in the parliament follow what the majority in Iran consider their rights of wearing according to their own norms.

\section{3. "Hijab e Kamel": Complete Hijab}

Muslim women have the options to choose between western wear and Islamic attire while deciding their formal dress wardrobe. Although many consider this choice as something to their advantage, this is the main reason behind their confusion in finalizing what to wear. In Iran, though, the situation is different and there is a type of dressing code which is considered complete officially and supported by the government. The Supreme Leader of Iran also hinted to the importance of compliance with the best Hijab, which is Chador, for women as he said that:

In my opinion, the debate about women's dressing code is one of the best debates; however, it should be noted that no discussion of women's wearing code is affected by the influx of Western propaganda; if it is affected, it will be ruined. For example, let's think with ourselves that we have a veil, but not Chador; this is a false idea. Not that I want to say that the Chador is a unique type; no, I say that the Chador is the best type of veil; it is a national mark; it has no drawbacks; it does not bring any restrictions whatsoever for women's freedom of movement and working. If it really is about the creation of social mobility and political work and intellectual work, the official dress of a woman can be Chador and - as I said - the Chador is the best type of veil. (Khabaronline, June, 2011)

Critical Race Feminism ("CRF") has a global appeal and puts more emphasis on the situation of women of color, while what we see today is a common problem for all of the women, in a special discriminatory way by choosing what is the best for them to do, wear, or even decide in elections. This much broader perspective can lift veil of ignorance of the debate concerning how much free women are in their decisions and brings the legal framework under serious question over the implications of such rights. As Professor Mari Matsuda described the "Multiple Consciousness" the women of color may feel, we have to consider much broader religious element added to the much more common elements of Race/Ethnicity and Gender. Just as the debate in Iran shows, the religious perspectives do interfere with the normal process of thought for women as to what the best dressing code is for them and how they should be presented in the society.

\section{Linguistic Perspective on Hijab}

There is an important linguistic load attached to the Islamic weight in Iran which should be considered in order to find the way the Islamic veil influences the whole society and makes the gender inequality harsher and even harder to recognize. The word to describe the Chador, or traditional long black veil, is Hijab-e-kamel which means complete Hijab. In fact, nowadays in Iranian society, when they talk about "Hijab-e-kamel", people understand it as Chador. The linguistic variable makes mind more unconscious as well as open to accept what they hear all the time as the norm and identity. Other Persian word for complete Hijab is Pooshesh Kamel which means complete coverage. It is interesting that this kind of word choice reflects the rather complete aspect of Chador. In fact, the emphasis is in the adjective Kamel (perfect) and this is a grwat psychological load on any women wishing to enter into politics. Figure 1 illustrates the psychological effect on women in general. 


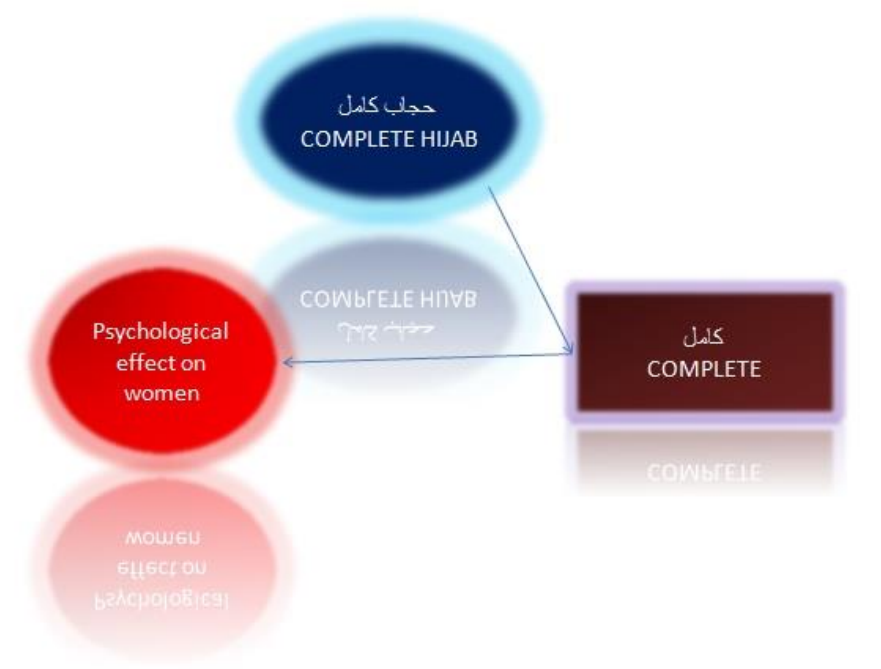

Figure 1. Psycholinguistics of Hijab e Kamel (perfect Hijab)

\section{Identity and Hijab}

It is important to pinpoint the relation between identity and gender as it does influence the whole spectrum of gender-specific issues in the region. Before anything, it's necessary to explain what we mean by identity. By identity we mean social categories in which an individual claims membership as well as the personal meaning associated with those categories (Ashmore et al. 2004). There is also Identity in psychological terms relates to awareness of self or what is known as self-image, self-reflection, and self-esteem. If we go down the road to meet the contemporary American society's definition we come up with the identity as a quality that enables the expression of the individual's authentic sense of self. The specific definition of intersectionality varies according different researches and their specific field but Shields (2008) define it as " social identities which serve as organizing features of social relations, mutually constitute, reinforce, and naturalize one another" and he later define mutually constituting as "that one category of identity, such as gender, takes its meaning as a category in relation to another category" and by reinforcing it means "that the formation and maintenance of identity categories is a dynamic process in which the individual herself or himself is actively engaged" (p.302).

Thus identity plays a huge role in the very definition of intersectionality and that's why we see the Hijab variable important as it does build an identity for different participants in the Iranian social life. Those who choose the complete Hijab develops an identity which is closest to the government and decisive bodies and those who goes with lesser Hijab builds a very different identity for themselves in the Middle-Eastern context. These different identities influence the way intersectionality forms and why we consider the Hijab and dressing code as the variable primordial to any analysis in the Middle-Eastern context. Intersectionality first and foremost reflects the very fact that reality exists but in different forms based on different identities.

As Shields (2008) describes:" The facts of our lives reveal that there is no single identity category that satisfactorily describes how we respond to our social environment or are responded to by others. It is important to begin with this observation because concern about intersectionality from a theoretical or research perspective has grown directly out of the way in which multiple identities are experienced" and goes to say that "Identities are fluid in that they can change over time; at the same time, however, they are experienced as stable, giving the self a sense of continuity across time and location. Some identity categories, perhaps most notably gender, are found in all historical periods and cultures, though how and to whom the identity category applies can vary as do the social meanings attached to the category". (p.304)

When we look at the Official Iranian TV channels, we cannot but wonder how the preferences seem almost always the same. The Chador is being used more than ever in these channels to provide role model for other women and this is not restricted to the media. As we mentioned above, in the Majlis, Iranian Parliament, the majority of women, regardless of which party they support, follow the official dressing code and wear Chador as the Complete Hijab. Figure2 shows the complex relations between Hijab, tradition, identity and gender. 


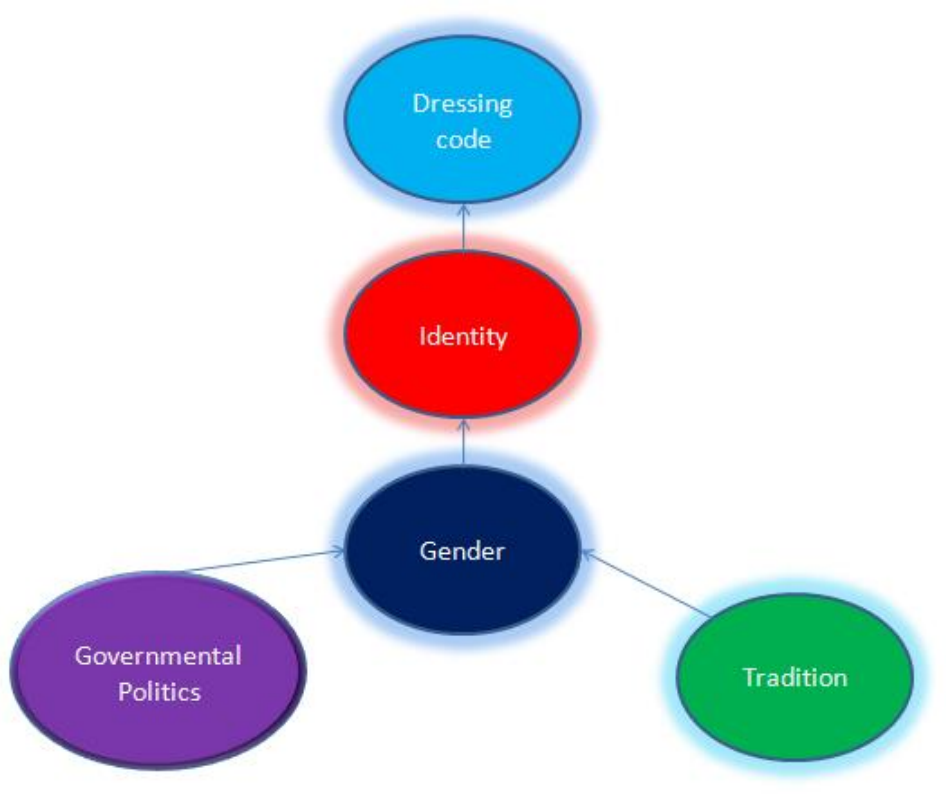

Figure 2. Interplay between politics, gender, tradition and identity

An adequate intersectional framework for understanding the conditions under which Iranian women are recognized as subjects in Iranian public should be considered to forms of racism. The fact that women who refuse to wear Chador, the complete Hijab, suffer discrimination should be investigated as a facet of racial discrimination. The reason to include these women as racially discriminated is that they are linked with the Western, non Islamic culture. In fact, in Iranian case, the racial discrimination does not have any skin color difference attached to it. It is a psychological conception of racial difference because of the Western/Islamic divide line.

Women who do not wear complete veil are considered to be somehow representative of a different race in Iran, even though these women are not in reality racially different. This is a new type of racial discrimination that is culturally and religiously formed rather than being directly influenced by race. The lingering insistence that Western culture can only harm the Islamic culture and bring inequality for Muslim women in Iran is expressed in the name of Islamic conservatism and Iranian political system, but it relies in fact on the structures of race and different psychological forms of racism: Western culture is seen as anti-Islamic that will influence the youth to change their identity and beliefs. They consider that hijab and wearing the complete Hijab create a high-power religious atmosphere and somehow insures the society from any harm; therefore, they consider that the first option to disarm Iranian religious society has been Hijab, not even other Islamic obligations such as fasting and prayers because Hijab represents the social identity for the Muslim community.

They consider Western values as a modern, changing and corrupt culture; cultures in which Western values dominate are assumed to be inevitably corrupt, obscene and inferior to "Islamic" cultures, downplaying the human rights as Western human rights, divorced from the Islamic jurisprudence. This clearly shows racial discrimination along the religious beliefs which produce racialized population as having "origin" out of the Islamic faith and Iranian sphere. This kind of understanding of Western culture is one of the many differences that can be categorized as intersectional between religion, culture and race. Ignoring the racial factor will definitely twist the whole picture incorrectly.

\section{Conclusion}

Intersectionality retains analytic usefulness for feminist Iranian studies, especially if we 1) insist on the importance of recognition that history and Western colonialism in the knowledge production, 2) keep open the flux of intersectional understanding, recognizing a number of religious specific, historical oriented and, interactional processes that creates a real embedding of politics and power struggle in the very fabrics of society. By adopting a model where dressing code is an important variable, we think the intersectional model for gender studies will be much more qualified for empirical methodology. As we explained in this study, the importance of recognition that there is an important divide between what is considered a correct Hijab and what is considered a lesser Hijab plays big in the Iranian politics and this comes directly from the gender divide in the country, how the media illustrates 
women, how the whole government wants to showcase women in the public as its own asset, and the wider religious perspectives that are dictated from different sources. Any research that wants to work on the gender issue in the region cannot go passing the complex but yet decisive Hijab variable in the Middle-East. Lastly, intersectionality is urgent because it should be a central concern not only for women but also those who try to develop human rights frameworks.

\section{References}

Ashmore, R. D., Deaux, K., \& McLaughlin-Volpe, T. (2004). An organizing framework for collective identity: articulation and significance of multidimensionality. Psychological Bulletin, 130, 80-114. https://doi.org/10.1037/0033-2909.130.1.80

Morawski, J. (1994). Practicing feminisms, reconstructing psychology: notes on a liminal science. Ann Arbor, MI: University of Michigan Press. https://doi.org/10.3998/mpub.10112

Purdie-Vaughns, V., \& Eibach, R. P. (2008). Intersectional invisibility: The ideological sources and social consequences of the nonprototypicality of intersectional subordinates. Sex Roles.

Singh, R. (2018). Derivational Grammar Model and Basket Verb: A Novel Approach to the Inflectional Phrase in the Generative Grammar and Cognitive Processing. English Linguistics Research, 7(2). https://doi.org/10.5430/elr.v7n2p9

Singh, R. (2018). Persian Spatial Prepositions: A Novel Logical Syntactical Approach to the Spatial Prepositions. Studii şi cercetări filologice. Seria Limbi Străine Aplicate. Retrieved from http://scf-lsa.info/wp-content/uploads/2019/02/55-60-RAJDEEP-SINGH.pdf

Singh, R. (2018). A Cognitive Approach to the Semantics in the Sacred Context: Semantic and Symbolic Function of Sacred Words. English Linguistics Research, 7(3). https://doi.org/10.5430/elr.v7n3p1

Singh, R. (2018). Norwegian and Persian spatial prepositions: a novel comparative and syntactic approach to the spatial prepositions. KAAV international journal of English, literature, and linguistics, 5, 1-8. Retrieved from: http://www.kaavpublications.org/journals/journal-5/article/article-1788.pdf

Singh, R. (2018). Areas of errors and difficulty for persian learners of spanish caused by the sound system differences between persian and spanish: a phonetic approach to inter-lingual system. KAAV international journal of English, literature, and linguistics, 5, 1-8. Retrieved from: http://www.kaavpublications.org/journals/journal-5/abstract/abstract-1996.pdf

Singh, R. (2018). Mirroring Effects and the Water Code: A Cognitive-Semantic Approach to Natural Morphology in the Religious-Cultural Context. Journal of Literature, Languages and Linguistics, 46, 37-41. Retrieved from: https://iiste.org/Journals/index.php/JLLL/article/download/43453/44769

Singh, R. (2018). Russian and Negative Prefixing: A Cognitive-Semantic Approach to the Negative Adjective Prefixing in Russian, Spanish, Persian, and English. English Linguistics Research, 7(4). https://doi.org/10.5430/elr.v7n4p7

Singh, R. (2018). Auxiliary Verbs in Serbo-Croatian, French, Persian, Spanish and English: A Cognitive-Semantic Approach to the Auxiliary Verb Usage and Passive Voice. English Linguistics Research, 7(3). https://doi.org/10.5430/elr.v7n3p34

Singh, R. (2018). Language change and directionality: A novel model for language change in Persian and Iranian languages from the sociolinguistic perspective. KAAV International journal of English, Literature, and linguistics, 5, 1-8. Retrieved from: http://www.kaavpublications.org/journals/journal-5/article/article-1876.pdf

Singh, R. (2018). Error Analysis of Persian Learners of Hausa Language: Cognitive Approach to Errors. Journal of Literature, Languages and Linguistics, 45, 10-15. Retrieved from: https://iiste.org/Journals/index.php/JLLL/article/view/42853/44147

Singh, R. (2018). Albanian World-View: Co-Locativity as the Schematic Meaning of Albanian Verbal Prefix Bashke-. English Linguistics Research, 7(4).

Singh, R. (2018). Christian And Sikh Communities In Iran And Role Of Language Identity: A Comparative Approach To The Social-Linguistic Aspects Of The Christianity And Sikhism In The Middle East. Sikh Research Journal, $3(1)$.

Singh, R. (2019). Rajdeep Singh, the Peace Poet: Analysis of Figurative Language Used in 'La paz que venga con 
fuerza’ Poem by Rajdeep Singh. Journal of Literature, Languages and Linguistics, 53.

Singh, R. (2019). Niedźwiedzia Przysługa? Bear's Favor? Hidden Garden behind the Concrete Proverbs: Cognitive-Semantic Analysis of Proverbs in Persian, Polish and Spanish. English Linguistics Research, 8(1). https://doi.org/10.5430/elr.v8n1p20

Singh, R. (2019). Iranian Civil Rights Movement and Independence Movement in Kosovo? European Union's Role in the Freedom Movements and State-Building. English Linguistics Research, 8(1). https://doi.org/10.5430/elr.v8n1p8

Shields, S. (2008). Gender: An intersectionality perspective. Sex Roles, 59, 301-311. https://doi.org/10.1007/s11199-008-9501-8

Stewart, A. J., \& Dottolo, A. L. (2006). Feminist psychology. Signs, 31, 493-509. https://doi.org/10.1086/491683 